\title{
The Role of Education in Transforming the Potential Social Skills of College Students
}

\author{
Kuwi Hoi New ${ }^{\mathrm{a}, *}$ and Mohamed Najib Abdul Ghafar ${ }^{\mathrm{b}}$ \\ ${ }^{a}$ Southern University College, Malaysia \\ ${ }^{\mathrm{b}}$ University of Technology, Malaysia
}

\begin{abstract}
This study advances "transformation" as the role of education in changing individual lives, and offers it as central to a theoretical framework that enables one to understand college education and the development of students in institutions of higher learning. Using a qualitative analytical approach, with in-depth field interviews, this research proposes a model that clarifies the process by which students are transformed into fully potential individuals as a consequence of their college experience. Education transforms both societies and people in a particular direction by shaping and reshaping their patterns of thoughts, means of problem solving and ways of life. This will then contribute to further individual and social transformation. This study finds that the process of education enables significant changes in students by contributing to the social skills that transform their identity and ultimately their society.
\end{abstract}

\begin{abstract}
Abstrak
Studi ini mendalami tema "transformasi” sebagai peran pendidikan dalam mengubah hidup seseorang, dan menempatkannya sebagai inti landasan teori untuk memahami pembelajaran di pendidikan tinggi dan perkembangan siswa di institusi pendidikan yang lebih tinggi. Dengan pendekatan analitis kualitatif, dan wawancara mendalam di lapangan, penelitian ini memaparkan sebuah model yang menggambarkan proses transformasi siswa menjadi manusia utuh, sebagai buah pengalaman mereka di universitas. Pendidikan mengubah masyarakat dan individu dengan membentuk dan membentuk-ulang pola pikir, cara pemecahan masalah dan pandangan hidup mereka. Upaya pendidikan ini akan mempengaruhi proses transformasi sosial dan individu. Studi ini membuktikan bahwa proses pendidikan memungkinkan terjadinya perubahan yang signifikan pada generasi muda dengan memberikan keterampilan sosial yang menggubah identitas mereka sendiri dan komunitasnya.
\end{abstract}

Keywords: Education, Transformation, College Students, Potential, Social Skills

\section{Introduction}

The social skills acquired by college students are very important in helping them to transform their initial capabilities into those that will allow them to reach their full potential. When students possess affective language skills, become pro-active and self-aware, they will be prepared to attain their goals (Domaine 1981; Bjarnason and Coldstream 2003 and Watson 2007). This research has found that the elements of social skills include the capacity to be pro-active, willing to contribute, appreciative, respectful of ethnic differences, prepared for the future, ready for change, highly flexible and high in self-expectations. If these skills are acquired, a student's social competencies will permit him or

*Corresponding author. Address: 15km, Jalan Skudai, 81300 Skudai, Johoe, Malaysia.

Email: khnew@sc.edu.my. her to move to a higher level of achievement. A student's potential (the capacity for advancement) allows him or her to advance to that stage where it is possible not only to achieve self-fulfillment but also to acquire the capacity for making a significant contribution to society.

\section{Theoretical Background}

Sociology is a scientific discipline whose task it is to establish objective knowledge concerning social phenomenon (Hurn 1978; Hughes and Kroehler 2009; Ritzer 2009; Rury 2009). One of its major concerns is the better understanding of education. The world is increasingly a knowledge interdependent complex (Cullingford and Gunn 2005; Marginson 2006; Altbach 2007), a complex in which we all need to be able to work together, to know about each other well and learn how to build bridges to the future. 
These are the skills and capabilities that liberal education provides by helping students develop their creativity, critical thinking, communication skills, cultural sensitivity, all of which are needed if people of diverse cultures are to work together both locally and globally. The soft skills that are provided by education, the values made available through the liberal arts, are extremely important in our ever more complex world.

Higher education is transformative; it allows gifted individuals to rise, and contribute in new, more powerful ways to the common good of society (Mok and Tan 2004). It equips individuals to make the best use of their talents and of the opportunities offered by society for self-fulfillment (Archer 1979; Bjarnason and Coldstream, 2003; Morshidi 2005; Tomlinson 2005; Moris 2007). Higher education prepares students to fulfill specialized social functions in the society. Private colleges and universities complement the efforts of their public counterpart in meeting the nation's manpower and professional needs (Haralambos and Heald 1985; Rashid 2002; Gorard 2007; Kamarul and Munir 2008; McIntyre 2008; McMahon 2009) believe that higher education makes a positive impact on life, as reflected in larger earnings and other non-pecuniary aspects of life such as higher social status. More recently economists have determined that the relative income of college graduates is at an all-time high. Health benefits derived from education are due to a greater capacity to choose lifestyles and demonstrate more future-oriented behavior. Robert Innes (2004), John Edward (2006) and David Watson (2007) also point out that higher education facilitates a wiser and more frequent use of health care services. Community members expect students to learn the skills necessary to become productive citizens. According to the Functionalist view, students learn the values that are essential for survival in the workforce through formal and informal means.

There may be a thousand and one definitions of education, but some significant ones may be highlighted here. Education is defined by Emile Durkheim (1858-1917) as the process by which the individual acquires the physical, intellectual and moral tools needed to function in society: "Man" is the only creature that has to be educated." Man can only become man through education (Parson and Platt 1973; Peter 1973; Pollack 2007; Ritzer 2008). Thus, the factors that lie behind education are a great mystery related to the perfection of human nature. These thoughts are congruent with Forrest Peterson (1980), Ronald Barrett (1994), Syed Hussein Alatas (1999), Abdul Rashid (2002) and Brent Ruben (2004), who view the aims of education to be the improvement of humans by helping them to understand things better. Education is able to increase our understanding of that which is known, and is thus it plays a profoundly important role character development. It is an activity that aims to bring about change. The purpose of edu- cation is to imbue man with a philosophy of life that becomes a guide (Peters 1973; Bell 1974; Alatas 1999; Vanderstraeton 2007). The idea of education implies that educators have the possibility of effecting change on those to whom their educational efforts are directed.

\section{The Relevance of This Study}

Each semester a substantial number of students come to college with all the right prerequisites and grades. All around the country, there are thousands and thousands of students ages 19 to 25 who enroll for a further study. These students are here to participate in a new mode of life, while in most instances they do not know what they are supposed to know. Their growth from naïve to knowledgeable is what people call education. This study focuses on the social aspects of change as it happens to these young people. It strives, by examining and coming to understand the process of behavioral change among the students, to help colleges set policies and establish environments that will help their students mature.

The social networks of students are very important for their maturation, especially in diverse and globalized world. They significantly affect the ability of individuals to be included within a society. Mark Abrahamson (1981), David DeCenzo and Beth Silhanek (2002), Svava Bjarnason and Patrick Coldstream (2003), Watson (2007) and Heath and her colleagues (2008) strongly believe that social and organizational factors shape the collective experiences of students. Students who are able to adapt are more likely to gain in personal development. The more diversity among the people whom students meet in college, the adaptability more they will manifest in the working world (Astin 1985; Pascarella and Terenzini 1991, 2005; Bjarnason and Coldstream 2003; McNay 2006). Every society seeks to replicate itself and finds ways of transmitting what is considered worthwhile to its young citizens. Thus, formal education is used to transform students into effective contributors to the creation of a more soundly evolving society in our ever evolving world. This view is supported Gary Becker (1975), Craig Calhoun, Jonathan Tudge, Michale Shanahan and Jaan Valsiner (1997), David Matheson and Ian Grosvenor (1999), and Jonathan (2001), John Rury (2009) and Nina Brown (2009), who suggest that social class, as determined in large part by education, both reflects and causes major social, economic and cultural differences with respect to income (pay packet, salary, dividends), wealth (what people own; housing, shares, money in the bank and possession), status and lifestyle. For this reason, colleges and universities must be ever conscious of the diversity of their students. 


\section{College Students and Their Transformation}

In this section we introduce three complementary areas help in the potential development of students (see Figure 1).

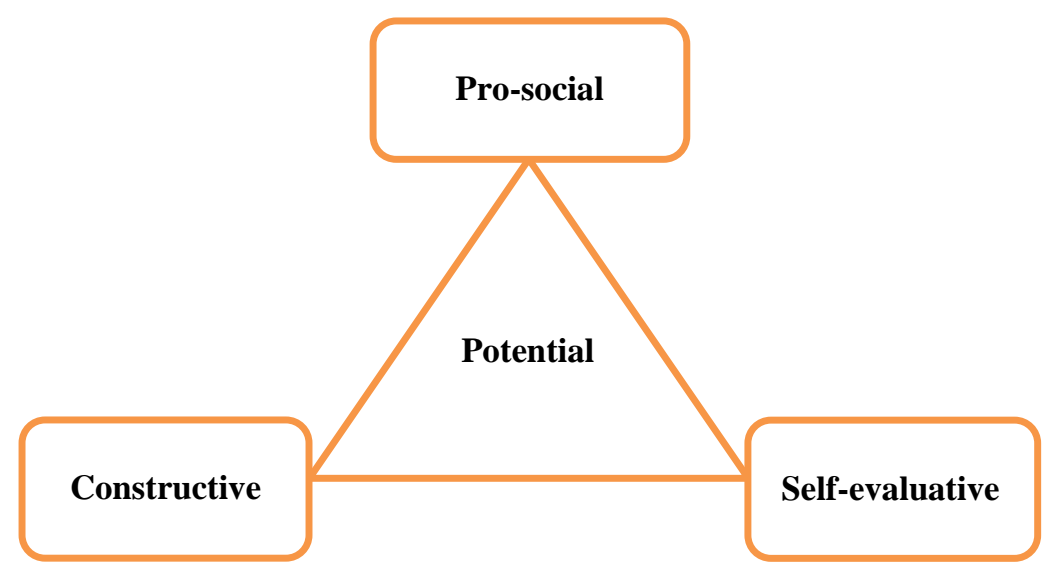

Figure 1. Student Potential

\section{Pro-social}

Pro-social actions are those actions that are voluntarily carried out for the sole purpose of helping others. It includes acts that contribute to the wellbeing of others without expectations of rewards. Actions such as helping others and being charitable and may be inborn tendencies. James Alcock, D. W. Carment, and S. W. Sadava (1994) and Clark (2003) highlight the fact that such acts are positively valued by society. Being pro-social involves behavior that has the social consequences and contributes to the wellbeing of others in society. Alcock, Carment, and Sadava (1994), David Clarke (2003), and G. M. Vaughan and Michael Hogg (2008) support the contention that pro-social acts are those that are voluntarily carried out for the sole purpose of helping others without expectations of rewards from external sources. Actions such are helping people, sharing, cooperating with and comforting others: these are pro-social actions that college students often possess but often avoid speaking about directly because it would be considered bragging. Their presence as a trait most often has to be derived from an interpretation of the context.

Interestingly, this research finds that a student who is proactive will take the initiative in finding ways and means to overcome problems. He or she will also try to find the factors that contribute to a desired result. This research finds that being pro-active allows students to involve themselves actively in social networking and helps them to accept criticism from peers. These are some of the comments made during the interviews: "Teachers are not correct all the time; we must have our own ideas and ways of thinking. People must interact. I like to do business. Internet is so well connected. I am now getting all juniors to come together ... to work out something." One participant stated "I will ask others to give comments and suggestions. Then I gather all ideas. Compare among each one, I study each of them. I will spend time to analyze them. I mean I do all the homework. Then I will make the decision." Another commented "One must be pro-active and sensitive to the environment, be flexible. Supposing there are A, B, C, and $\mathrm{D}$ types of environment, to survive one must change according to the environment, knowing how to adapt and then to move on. I am the one who approaching others most of the time. I am active, have initiative and am aggressive. I dislike doing things when asked. I do things before people ask me to do them. I show my best, I show the results; I take initiative, I am pro-active. When I organize activities for all students, I observe and ask the committee members to give their suggestions. Then I will decide and carry it out. I do my homework. I prepare and think of all kinds of alternatives.” One male participant stated "I go to an Indian temple, Buddhist temple, and Islamic mosque. I just go in because of my attitudes. I wish to know what is inside there. I learn and get to know many things. I am a positive person.” While another female participant explained "I am active, but not over active. After I came to this college I became more active.” One participant expressed it this way: "I will change and listen to criticism. I want to be a better person in doing my design as in sport."

This study has revealed that a good number of students are willing to contribute both to their family and to the society. A student who possesses this willingness to help others will in most cases do so to the best of their ability. Individuals will also try to lessen their parents' burden by helping with household chores or finding a part time job. These are some comments from participants: "I took part in LEO club, sport activities, I adapt to it. Extra curriculum is good for students. ... So, I prefer to come to college, to get involve with club and sport activities. I had changed to be more devoted and caring. I love to organize activities for old citizens and do charity fund raising. I am the host for most of the charity shows in Leo Club, I proudly declare here.” Another participant put it explicitly "If I have more money, I will do charity. I will care for others. I think humans like us should be more caring and warm at heart. So, I always show my smiling face whenever I met someone, to me this will cheer them up, I dislike my childhood experiences that were cool in everyone's face. It was very scary. Life is not only like this, it should be more.” One male participant commented "I should be able to help and do more things for my family. I am a grown up son.” Another participant reflected "My cousin, he has problems in his relationship. His girlfriend dates other guys. He has a heartbroken. So I bring him to do charity works; we go to old forks homes, spastics, orphanages and so 
on, so that he can meet lots of people. He is able to fill up his leisure time meaningfully. I'm scared he might end up getting depressed or go crazy.” One male participant presented himself this way: "I join the praying group to pray for the dead ones. I even thought of being a monk." Another participant stated "I treat them well. I love to help them. I chit chat with them and am sociable. We have fun, share creative ideas, knowing the environment and are focus.”

Potentially successful individuals possess the ability to appreciate the actions of others. Appreciation involves the ability to acknowledge and be grateful for what others have done for them (Vaughan and Hogg 2008; Kottler and Carlson 2010). This is observed when students mention that they appreciate their family, parents, friends, teachers for having done things for them. Individuals have the ability to treasure and highly value those people around them who make sacrifices for their benefit. It is found that a considerable number of college students have the ability to appreciate others in the process of social change. These are some quotes from the field interviews; one participant stated "I have learnt to appreciate. In the past everything seemed to be taken for granted. For what I have now, I appreciate it very much specially this department. There are many people who help me. God is so good to me. They all support me, trust me and respect me." Another person stated "I think I should go to study some more. I may be too slow. One colleague worked for 11 years and got scolded every day. In those years he was scolded. Too bad isn't it? Now, I appreciate his scolds.” One male participant put it this way: "Working made me feel hurt, bad. It made me know studying is very important. Working made me loss my confident. I work hard to pay back to my mother ... my father both of them were old. My father had retired long ago, while mother is going to retired soon. I must do something to provide them shuttle and for four of us." Another participant explained "I'm glad and I appreciate whatever I have now. Not to the best, but I am happy.” Another of the participants stated "I became more mature and I appreciate life. I treasure what I have very much. When I work it is just like stepping into the real world. While I study than I know that working and study can be both quite different. Theory and practical might not be the same, so when I work now it is like complementing with each other. I think I must be able to treasure things and appreciate what I have. Little brother gave me a warm heart, I learn a lot from him, he takes me as a brother, and we can stay together. I will always treasure him." Yet another reported "I treasure it very much. I can stand in front of the stage I feel fortunate and grateful. So, I am better. I appreciate what I have now. I should say that I am better than I was last time.”

Interestingly, another element of social skills that emerged from the field data analysis is respect. As stated in Neil Smelsler
(1988), Christopher Mruk (1999), Vaughan and Hogg (2008), and Jeffrey Kottler and Matt Carlson (2010), respect for individual differences begins with acknowledging the existence of differences among the groups and coming to understand that individuals have the ability but not always the willingness to respect the differences of other people. The field data analysis supports this contention with the following statements; "In secondary school, we had not learnt it but in UEC they had learnt it. So, there were 2 groups in class. The UEC group is good, while the SMK group is not good. They are difference in ability." One male participant explained "I can work with various ethnic students. Respect! We play together and we respect each other." Another participant remarked "They respect me very much. There were three of us; one monitor and two assistant monitors. I always give the others opportunities. I always respect them.” One female participant explained herself explicitly by stating: "I always treat people as I want them to treat me. I always treat them well; respect them, listen to them, and provide an opportunity for them to express their ideas and views. Respect is important.”

An individual's preparedness for future is a one of the important elements at the stage of developing one's potential. Individuals are usually psychologically prepared to change according to the needs of the context. Being prepared means that the individual has the potential to attain a goal of life. He or she is able to visualize the future and be mentally prepared for the worst. This is supported by Vaughan and Hogg (2008), Brown (2009), and Kottler and Carlson (2010). An Individual at this stage is being prepared to go all out to attain a goal of life. The following comments are offered as evidence, with one participant indicating "Planning well and put in effort to achieve it. We must set our targets. Yes, I plan to. I want to go to Australia or New Zealand. I'll work first, and then only I will continue my studies if possible, I do not want to come back. I want to be a programmer, generate system, that kind of thing." Another participant stated "I want to study further in film and TV. Beside that I want to study foreign languages; for example, French or Japanese. I love languages.” Yet another stated "I am good in event planning; I am going to start a company that involves in organizing events and activities or annual dinner for institution or organization.” One female participant put it this way: "I want to go to Singapore MDIS College. It is our sister college. If I go to Taiwan or China I may get full scholarship, but I want to study in English. I want to have a change, and I think Singapore is better. Even Taiwan offers full scholarship.” Another participant indicated that "I want to have my own career. Right now, I will look for a job and I intend to show them my portfolio, I must show them my ability." Another participant said "I want to be a computer programmer. They are many programmers in the market. So, I need to be different or outstanding. Even if there are 
many degree or master holders, I must have my specialty. I need to improve my ability and creative ideas. I am quite low in interaction communication.”

Readiness for change is another important element at this stage. Most potentially successful individuals strive to be flexible and to respond positively to the changes that arise. They try as best they can to deal with change. An Individual at this stage should be ready to go forward and experience something new. He or she must be willing to take on new ideas, be open minded, reflective and take feedback seriously (Vaughan and Hogg 2008; Brown 2009; Kottler and Carlson 2010). This is supported by Durkheim (1958), Richard Peter (1973), Abdul Rashid (2002), and John Scott (2006) who argue that education itself must change, and one must remain sufficiently flexible to allow for change. Sherry Holladay and Timothy Coombs (1994) and Gail Fairhurst (2001) both have indicated that this type of leader is a transformational leader who brings about changes. Education has varied infinitely over time and varies from place to place, but traditionally it has tried to make of the individual autonomous. Here are some comments from the participants: "Computer software is a user friendly interface. A computer is more humanistic. Like Windows XP new version is user friendly. So, it took two days to get used to it. I give them but old people always think that I bully them." One participant stated "Before I came, I had very low in self-esteem. I had to change myself to be more active and outgoing. I never realize until my friends told me. I am more positive now.” Another strongly proposed "As a student's one must be ready for change and getting more exposure. I think students are just young, experiences and environment will determine the character of that person, It is difficult to change when they grew older. I would say that interest must be developing at young age; the most important thing is how to maintain and keep it longer. College did change me, I think.” Yet another stated "This College is as a stepping stone, slowly I like it. I did expect some changes before I came.” One participant expressed it this way: "I must change. I want to be better. I want to progress. Every day before I sleep, I think it over again and again since form three. Then I use to continue it just like this."

High self-expectation is another valuable element in this stage. Potentially successful individuals are inclined to expect themselves to perform the tasks given to them effectively. They are generally found to be positive about their abilities and are always looking forward to a better future. This finding is supported by Smelser (1988), Barbara Rogoff (1997), Will McWhinney (1997), Ehrhart and Klein (2001), Robert Gonyea (2006), and Katherine Adams and Gloria Galanes (2009). The individual at this stage is always aiming at a higher level of achievement and dares to take challenges. These are relevant quotations from the interviews; one participant explaining explicitly "Even now it is still with me. For group assignments, since semester one to this day, I give 100 percent effort. I want to get 100 points." Another said "I want to get 4.0 GPA." Another participant stated "Now I think that I can do more or better in my study." One female participant described it this way: "I want to change to be a stronger person. Crying is soft type of thing; it shows that I am weak. I want to change to be a 'strong' girl." Another male participant said "I think is my attitude. Not good enough. I want to be a chef. I want to be scientist.” One even said "I always have high self-expectations. I am disciplined and responsible;" and yet another "I think there are so many things which I have to upgrade further. Takes for example, many of my friends go to Open University for more studies.”

High flexibility is a one of the most important elements in developing one's potential. Successful individuals are always flexible and are able to change according to the needs of the circumstances. This study reveals that being flexible, means that the individual is a creative problem solver. He or she is able to respond to the most subtle nuances of human behavior. They are able to deal with behavior that is changing rapidly and is able to react to those changes both internally and externally. This finding is supported by Vaughan and Hogg (2008), Brown (2009), and Kottler and Carlson (2010). An Individual at this stage is being prepared to throw away their agenda, so that can respond effectively to the new issues that arise. These are some comments from the in-depth interviews: “I now feel like 'I am just like a bottle of water.' I've become very flexible. I can adjust myself easily.” One participant stated "I think I must be flexible in my situation and see how I can move onwards in the working industry. I'm open minded and willing to learn. I shall apply ways and methods which I had learnt to help me in my career. Attitude to face changes is important. Many people are scared of changes; mentally they are too scared to take changes." Another participant stated "The SMK teacher never taught, my brother he run away, the teacher was not teaching the class. Now, we allow him to stay at home and do his work. He is in the morning section this year. At least we know where he is." Yet another participant stated "It is quite challenging. I enjoy doing it. I love something challenging. I am creative and good in response. Doing things according to plan is sometimes very boring. Step to step all the time sometimes affects the whole program.”

\section{Constructive}

Constructiveness refers to the cognitive process of viewing situations in a positive light and having the capacity to cope effectively with the future. Student leaders with constructiveness are positive about their capabilities and the outcomes they can achieve, as has been found by Peter Northouse (2009, 2010). This 
capacity helps students fit into groups, such students are also able to look forward to a bright future and strive for a better public life. The value of constructiveness is particularly important for the educational achievements of students. These are some comments from the interviews: "I know myself better, I know what I want. No matter what kinds of people I meet, because I study I can be better. I think I should be able to cope in the future. This will help me in my career, human relations. For me I think I can also integrate myself into the university later." One participant supported this by saying "College prepares me for industry. I am fully prepared. It is because in this college; teachers, and environment are all okay. I had a very colorful and fruitful college life.” One other participant stated "They are people from whom I can learn . . . they also will nag . . . so I just listen . . . . But I learn how they handle their problems. We are learning all the time; I feel it is better to learn from them than read 100 pieces of a book."

\section{Self-evaluative}

Self-evaluation will help individuals to become more aware of their strengths and weaknesses and help them develop into competent members of society. This is concurs with the findings of Johnson (2009), Northouse (2009, 2010), who find that individuals at this stage are observed to be able to assess their own performance by knowing their potential. They are well prepared to take criticism and possess a high degree of self-awareness, as seen in these comments: one participant saying "Now I study because I want to achieve my dreams. I am too fast in pace. I don't study for exams. Before this, I always used my time to chase others. But here, I study not because of results. I am very happy.” One female participant stated "I do smiling more, not so moody or sad. I am happier. My good points are that I'm thoughtful, kindhearted and able to tolerate others. But I must be led by someone. I am very low in my self-concept. I am just too scared that I cannot achieve their expectation. Sometimes, I am not able to make decisions. I am happy.” Another participant expressed it explicitly: "I like to organize activities. I will do all my best; my close friends say that I am a thoughtful, fussy, a perfectionist in doing thing but not in study. I am very fair and rational to all my subordinate and good to all. I will communicate with them. I make it clear cut; official is official, personal is personal. I know what I must do. My point is that I want to live better, to have a better life and to be loved and to love someone whom loves me. It is important that I can play my role well and to be able to achieve happiness. I think so.” Another participant remarked "I am passionate, good listener, rational and kind-hearted. Beside that analytical and my attitude is good. I am good in customer service. I am scare of women. I still need to learn. I love cooking very much. I started cooking for my family in secondary, I enjoy doing it. I want to work as IT personnel. IT still has many areas and new knowledge which I can explore.” Another participant noted "I may be protected all this while. My home is better and more suitable for me, so I decided not to move into the hostel. I love programming subjects. I dislike theory such as System and Operation for example Windows, Apple, how computer works; technical knowledge of computer hardware. I enjoy looking at the output that I had produced." Another added "I am good in both design and programs. I did well in these. I like to do my things quietly. I am not pushy.” And yet another expressed it this way: "I like web design very much. I tried not involving in any running competition, but I still jog and run for keeping fit in the evening at campus. When I am in sport, it's really me. I am happy. With teachers I have problems in expressing my ideas. I cannot express myself.” Research finds that a fully transformed college student possesses the following traits (Figure 2).

These findings are in agreement with the research done by John Dewey (1966), Johnson (1996), Bjarnason and Coldstream (2003), Robert Moore (2004), Michael Young (2008) and Northouse (2009) who have find that at the heart of socialization is the growing awareness that the social world involves more than the individual's own experiences, and the needs for a society are more than those of the individuals who act, feel and think. Through the socialization process, individuals use values to create ideal selves and make judgments about them. Young people often select new models for their behavior and might reject parental values. For this reason institutions of higher education must be ever sensitive to the social as well as academic contribution they make to the maturation of their students.

\section{Concluding Remarks}

In summary, social skills refer to those elements that serve to maintain and vitalize the motivation of college students as they perform the roles established for them by social expectations. A system must furnish, maintain, and renew both the motivation of the college students and the cultural patterns that create and sustain that motivation. Potential not only refers to the individuals aptitudes, to the ability a group to furnish, maintain and renew the motivations of its members. It is embedded in the functionalist theory of stratification. It motivates individuals to strive to move up in the system and occupy a higher-level position. This motivation must not only be created by the system but constantly renewed in order to keep the system working and the people striving. Potential, at the macro level, refers to the need to sustain the system and keep people involved in striving to move to the top of that system. 


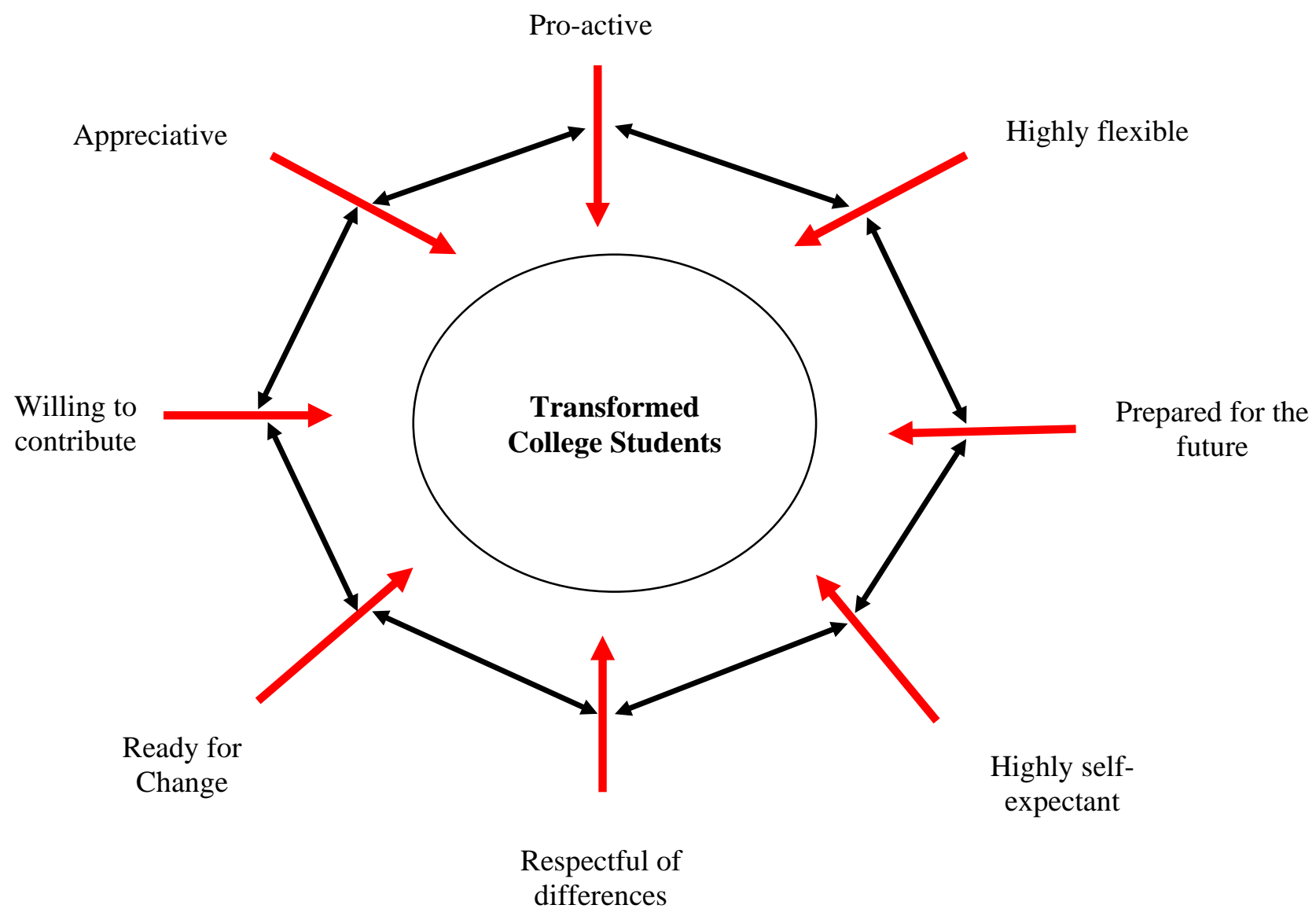

Figure 2. A Fully Transformed College Students Traits

The norms and values that support such a system and such striving must be firmly put into place and sustained. This study supports the findings of Carolyn Anderson, Bruce Riddle and Mathew Martin (1999), DeCenzo and Silhanek (2002), Schriver (2004), Watson (2007), Joan Grusec and Paul Hastings (2007), and Jon Nixon (2008) who find that the need for achievement will drive a person to excel, to a set of personal standards, to strive for success and develop his or her social potential. This study finds that the transformation that is the result of education does not have to rely solely on actions taken at the institutional level. Students who are actively involved in the interaction both in and out of the classroom and motivated by what is taught intentional and unintentionally across the experiences in college environment, will make a difference for everyone who is engaged in the process of higher education. Colleges and universities are not only educating students but are training them by providing important skills, so that they can perform in the society more effectively.

\section{References}

Abrahamson, Mark. 1981. Sociological Theory an Introduction to Concepts: Issues and Research. Englewood Cliffs, NJ: Prentice Hall, Inc.

Adam, Katherine, and Gloria J. Galanes. 2009. Communicating in Groups: Applications and Skills. New York: McGraw Hill Higher Education.

Alcock, James E., D. W. Carment, and S. W. Sadava. 1994. A Textbook of Social Psychology. 3rd ed. Scarborough, ON: Prentice-Hall.

Altbach, Philip. 2007. Tradition and Transition. The International Imperative of Higher Education. Rotterdam, Boston: Center for International Higher Education, Boston College and Sense Publishers.

Alatas, Syed Hussein. 1999. The Meaning of Progress in Contemporary Education. Bangi, Malaysia: University Kebangsaan Malaysia.

Anderson, Carolyn M., Bruce L. Riddle, and Matthew M. Martin. 1999. Socialization Processes in Groups in Communication Theory and Research. Thousand Oaks, CA: Sage Publications. 
Archer, Margaret. 1979. Social Origins of Education Systems. London: Sage Publications.

Astin, Alexander. 1985. Achieving Educational Excellence: A critical Assessment of Priorities and Practices in Higher Education. San Francisco: Jossey-Bass.

Barrett, Ronald. 1994. The Limits of Competence Knowledge of Higher Education and Society. Maidenhead, UK: Open University Press.

Becker. Gary. 1975. Human capital: A Theoretical and Empirical Analysis with Special Reference to Education. Chicago: University of Chicago Press.

Bell, Daniel. 1974. The Coming of the Post Industrial Society. London: Heinemann.

Bjarnason, Svava, and Patrick Coldstream. 2003. The Idea of Engagement Universities in Society. In Making Engagement Work in Practice, ed. Marilyn Wedgwood. London: Policy Research Unit the Association of Commonwealth Universities.

Brown, Nina W. 2009. Becoming a Group Leader. Upper Saddle River, NJ: Pearson Education.

Bruner, Jerome. 1960. The Process of Education. Cambridge, MA: Harvard University Press.

Bruner, Jerome. 1996. The Culture and Education. Cambridge, MA: Harvard University Press.

Calhoun, Craig, Donald Light, and Suzanne Keller. 1997. Sociology. 7th ed. New York: McGraw-Hill Inc.

Carr, David. 2003. Making Sense of Education. An Introduction to the Philosophy and Theory of Education and Teaching. New York; Routledge.

Clarke, David. 2003. Pro-social and Anti-social Behavior. London: Routledge.

Cullingford, Cedric, and Stan Gunn, eds. 2005. Globalization, Education \& Culture Shock. Aldershot, UK: Ashgate.

DeCenzo, David A., and B. Silhanek. 2002. Human Relations Personal \& Professional Development. 2nd ed. Upper Saddle River, NJ: Prentice Hall.

Dewey, John. 1966. Democracy and Education: An Introduction to the Philosophy of Education. New York: Free Press.

Domaine, J. 1981. Contemporary Theories in the Sociology of Education. London: The Macmillan Press Ltd.

Durkheim, Emile. 1958. Education and Sociology. London: The Free Press.

Edward, St. John. 2006. Education \& the Public Interest. School Reform: Public Finance \& Access to Higher Education. Dordrecht, The Netherlands: Springer.

Ehrhart, Mark G., and Katherine J. Klein. 2001.”Predicting followers' Preferences for Charismatic Leadership: The influence of follower Values and Personality.” Leadership Quarterly 12 (2): $153-180$.

Fairhurst, Gail T. 2001. Dualisms in Leadership Research. In The New Handbook of Organizational Communication: Advances Theory, Research and Methods, ed. F. M. Jablin and L. L. Putnam. Thousand Oaks, CA: Sage Publications.

Fragoulis, Iosif, and Niki Philips. 2011. "Social Skills for Successful Career Development.” Review of European Studies 3(1): 85-93.
Gonyea, Robert M. 2006. The Relationship between Student Engagement \& Selected Desirable Outcomes in the First Year of College. Paper presented at the 46th Annual Association for Institution Research Forum, Chicago, May 2006.

Gorard, Stephen. 2007. Overcoming the Barriers to Higher Education. Staffordshire, UK: Trentham Books.

Grusec, Joanand, and Paul D. Hastings. 2007. Handbook of Socialization Theory and Research. New York: The Guilford Press.

Haralambos, Michael, and R. M. Heald. 1985. Sociology: Themes Perspectives. 2nd ed. Boston: McGraw-Hill.

Heath, Sue, Alison Fuller, and Karen Paton. 2008. "NetworkBased Ambivalence and Education Decision Making: A Case Study of 'Non-participation' in Higher Education.” Research Papers in Education 23 (2): 219-229.

Holladay, Sherry J., and Timothy Coombs. 1994. "Speaking of Visions and Visions Being Spoken: An Exploration of the Effects of Content and Delivery on Perceptions of Leader Charisma.” Management Communication Quarterly 8: 165-188.

Innes, Robert B. 2004. Reconstructing Undergraduate Education Using Learning Science to Design Effective Courses. London: Lawrence Erlbaum Associates Publishers.

Johnson, A. G. 1996. Human Arrangements: An Introduction to Sociology. 4th ed. Madison, WI: Brown \& Benchmark Publishers.

Jonathan, R. 2001. "Higher Education Transformation \& the Public Good.” Kagisano Higher Education Discussion Series 1: 28-63.

Kottler, Jeffrey, and Matt E. Carlson. 2010. Learning Group Leadership: An Experiential Approach. 2nd ed. London: Sage Publications.

Marginson, Simon. 2007. "The Public? Private Divide in Higher Education: A global Revision.” Journal of Higher Education, 29 (3): 25-36.

Matheson, David, and Ian Grosvenor. 1999. An Introduction to the Study of Education. London: David Fulton Publisher.

McIntyre, L. J. 2008. The Practical Skeptic Core Concepts in Sociology. 4th ed. Boston: McGraw-Hill Higher Education.

McNay, Ian, ed. 2006. Beyond Mass Higher Education Building on Experience. London: Society for Research into Higher Education and Open University Press.

McMahon, Walter. 2009. The Private and Social Benefits' of Higher Education. Higher Learning, Greater Goal. Baltimore, MD: John Hopkins University Press.

McWhinney, Will. 1997. Paths of Change; Strategic Choices for Organization and Society. Thousand Oaks, CA: Sage Publications.

Mok, Ka Ho, and Jason Tan. 2004. Globalization and Marketization in Education. A Comparative Analysis of Hong Kong and Singapore. Cheltenham, UK: Edward Elgar Publishing.

Morshidi, Sirat. 2005. Working Paper Transnational Higher Education in Malaysia: Balancing benefits and concerns through regulations. Penang, Malaysia: National Higher Education Research Institute, Universiti Sains Malaysia. 
Moore, Robert. 2004. Education \& Society. Issues and Explanations in the Sociology of Education. Cambridge, UK Polity Press.

Moris, Zailan. 2007. 50 Tahun Pembangunan Pendidikan Tinggi di Malaysia (1957-2007). Pulau Pinang, Malaysia: Universiti Sains Malaysia.

Mruk, Christopher J. 1999. Self-Esteem: Research, Theory \& Practice. 2nd ed. New York: Springer.

Muhammad Kamarul Kabilan Abdullah, and Munir Shuib. 2008. "Enhancing Private Education in Malaysia: An Interview with the Forma Deputy Director General of the Department of Private Higher Education, Ministry of Education Ms. Arpah Mohammad.” Bulletin of Higher Education Research 11: 7-9.

Nixon, Jon. 2008. Towards the Virtuous University: The Moral Bases of Academic Practice. New York: Routledge.

Northouse, Peter G. 2009. Introduction to Leadership Concepts \& Practice. London: Sage Publications.

Northouse, Peter G. 2010. Leadership Theory \& Practice. 5th ed. London: Sage Publications.

Parson, Talcott, and Gerald Platt. 1973. The American University. Cambridge, MA: Harvard University Press.

Pascarella, Ernest T., and Patrick T. Terenzini. 1991. How College Affects Students: Findings and Insights from Twenty Years of Research. San Francisco: Jossey-Bass Publishers.

Pascarella, Ernet T., and Patrick T. Terenzini. 2005. How College Affects Students. San Francisco: Jossey-Bass.

Peter, Richard Stanley. 1966. Ethics \& Education. London: George Allen \& Unwin University Books.

Peters, Richard Stanley, ed. 1973. The Philosophy of Education. Oxford, UK: Oxford University Press.

Peterson, Forrest. 1980. John Dewey's Reconstruction in Philosophy. New York: Philosophical Library.

Pollack, Gary. 2007. "Philosophy of Education as philosophy: A Meta philosophical Inquiry.” Educational Theory 57 (3): 239260.

Rashid, Abdul, and Abdul Rahim. 2002. Education and Nation Formation in Malaysia: A Structural Analysis. Kuala Lumpur: University of Malaya Press.

Ritzer, George. 2008. Contemporary Sociological Theory \& Its Classical Roots. New York: McGraw Hall.

Rogoff, Barbara. 1997. "Evaluating Development in the Process of Participation: Theory, Methods \& Practice Building on each other." In Change and Development: Issues of Theory, Methods and Application, ed. E. Amsel and K. A. Renninger (pp. 205285). Mahwah, NJ: Erbaum.

Rury, John L. 2009. Education and Social Change: Contours in the History of American Schooling. 3rd ed. New York: Routledge.

Ruben, Brent D. 2004. Pursuing Excellence in Higher Education. Eight Fundamental Challenges. San Francisco: Jossey-Bass.

Schriver, Joe M. 2004. Human Behavior and the Social Environment: Shifting Paradigms in Essential Knowledge for Social Work Practice. 4th ed. Toronto: Pearson Education.

Scott, John. 2006. Social Theory Central Issues in Sociology. London: Sage Publications.
Smelser, Neil J. 1988. Sociology. 3rd ed. Englewood Cliffs, NJ: Prentice-Hall.

Southern College. 2006. Southern College Annual Report. Johor, Malaysia: Southern Press.

Thomas, Gary. 2007. Education and Theory: Strangers in Paradigms. London: Open University Press, McGraw Hill.

Tomlinson, Sally. 2005. 2nd ed. Education in a Post Welfare Society. London: Open University Press.

Tudge, Jonathan, Michael Shanahan, and Jaan Valsiner. 1997. Comparison in Human Development. Cambridge, UK: Cambridge University Press.

Vanderstraeton, Raf. 2006. “'How is Education Possible?’ Pragmatism, Communication and the Social Organization of Education.” Journal of Higher Education Research 52 (2):160-174.

Vaughan, G. M., and Michael A. Hogg. 2008. Introduction to Social Psychology. 5th ed. Frenchs Forest, NSW: Pearson Education.

Watson, David. 2007. Managing Civic and Community Engagement. London: McGraw-Hill. Open University Press.

Young, Michael F. 2008. Bringing Knowledge Back in From Social Constructivism to Social Realism in the Sociology of Education. London: Routledge. 